\title{
The irregularity of water consumption in settlements with varying numbers of inhabitants
}

\author{
Ewa Ogiołda ${ }^{1, *}$, Ireneusz Nowogoński ${ }^{2}$ \\ ${ }^{1}$ University of Zielona Góra, Faculty of Civil Engineering, Architecture and Environmental \\ Engineering, Institute of Environmental Engineering \\ ${ }^{2}$ University of Zielona Góra, Faculty of Civil Engineering, Architecture and Environmental \\ Engineering, Institute of Environmental Engineering
}

\begin{abstract}
The article presents an analysis of water consumption in selected settlement units of Lower Silesia and Lubuskie Provinces, with the number of inhabitants varying from less than 200 to more than 8000 . Based on data over several years, values characterizing water consumption in individual systems were calculated, i.e., the indicator of water consumption per capita as well as hourly and daily irregularity coefficients. Consumption during various time frames - in individual months of the year, days of the week and hours of the day - was also compiled. The obtained results were the bases for comparison with values provided by Guidelines, which are the basis for calculating for water demand; and Regulation, which is the basis for billing water consumption, as well as with the results of other authors. Tendencies characterizing water consumption in the subsequent years were also indicated. A typical weekly and daily (24-hour) course of consumption was observed, with the course being characteristic of small settlements with varying numbers of inhabitants.
\end{abstract}

\section{Introduction}

The demand for water is the basis of dimensioning individual elements of water supply systems. Serving as the basis for calculations are the "Guidelines for Programming Water Demand and the Amount of Wastewater in Urban Settlement Units" [1]. In Poland, limited water consumption has been observed for many years now, which may result from the use of water meters to measure water consumption and increased prices of water. The values of actual water consumption serve as the basis for characterizing and comparing individual systems as well as reflecting the habits and lifestyles of the water recipients using them. Water consumption is characterized by both its quantity as well as irregularity in various time frames, i.e. a year, week or day $[2,3]$. The specifics of water consumption in a given system, as well as differences between forecasted and actual values, are reflected in the level of hydraulic and quality parameters characterizing the system and are decisive to its proper exploitation and, as a consequence, its operational reliability [4].

\footnotetext{
*Corresponding author: e. ogiolda@iis.uz.zgora.p1
} 
An analysis of water consumption was carried out for a few water supply systems aiming to measure the indicators describing the amount and irregularity of water use, as well as the course of its variability. An analysis has been carried out to compare real values with "Guidelines".

\section{System characteristics}

The water supply systems which were subjected to analysis are located in Lower Silesia and Lubuskie Provinces, and vary in terms of both the intended water use as well as the number of recipients.

Four of the discussed systems are located in Lower Silesia Province, in the community of Głogów. These systems are [5, 6, 7, 8]:

- Turów, supplying water to the inhabitants of a single village,

- Serby, which supplies water to recipients in the villages of Grodziec Mały, Szczyglice, Ruszowice and Serby,

- Borek, covering the villages of Borek, Bytnik, Przedmoście and Zabornia,

- Wilków, which the villages of Wilków, Klucze, Krzekotów and Serby Stare are supplied from.

In the same province, in the community of Chocianów, there is a system supplying water to the inhabitants of Parchów and Pogorzeliska.

Water in the abovementioned systems is used for the needs of homesteads and farms.

Also analyzed was water consumption in systems supplying water to the cities of Chocianów - located in Lower Silesia Province, and Nowogród Bobrzański - located in Lubuskie Province.

The number of inhabitants supplied with water in the individual settlement units and the years from which data regarding use are derived, have been presented in Table 1.

Table 1. Number of water recipients and observation period in the individual water supply systems.

\begin{tabular}{|c|c|c|}
\hline System & $\begin{array}{c}\text { Number } \\
\text { of water } \\
\text { recipients }\end{array}$ & $\begin{array}{c}\text { Years of } \\
\text { observation }\end{array}$ \\
\hline Turów & 162 & $2000-2009$ \\
\hline $\begin{array}{c}\text { Parchów and } \\
\text { Pogorzeliska }\end{array}$ & 832 & $2009-2016$ \\
\hline Wilków & 1043 & $1995-2011$ \\
\hline Borek & 1200 & $1995-2011$ \\
\hline Serby & 3062 & $2000-2009$ \\
\hline $\begin{array}{c}\text { Nowogród } \\
\text { Bobrzański }\end{array}$ & 5617 & $2002-2013$ \\
\hline Chocianów & 8187 & $2009-2016$ \\
\hline
\end{tabular}

\section{Calculation methodology}

In order to compare the individual water supply systems, the values of coefficients describing the amount and irregularity of water consumption were calculated.

Indicators of water consumption per capita were calculated using the formula [9]: 


$$
q_{j}=\frac{Q_{d s r}}{M}
$$

where:

$\mathrm{q}_{\mathrm{j}}$ - indicator of water consumption per capita, $\mathrm{dm}^{3} \cdot \mathrm{M}^{-1} \cdot \mathrm{d}^{-1}$,

$\mathrm{M}$ - number of inhabitants,

$\mathrm{Q}_{\mathrm{d} \text { sr }}-$ average daily water consumption, $\mathrm{m}^{3} \cdot \mathrm{d}^{-1}$.

To calculate daily and hourly irregularity coefficients, the following formulas were applied [9]:

$$
\begin{aligned}
& N_{d}=\frac{Q_{d \max }}{Q_{d s r}} \\
& N_{h}=\frac{Q_{h \max }}{Q_{h s r}}
\end{aligned}
$$

where:

$\mathrm{Q}_{\mathrm{d} \text { sr }}$ - average daily water consumption, $\mathrm{m}^{3} \cdot \mathrm{d}^{-1}$,

$\mathrm{Q}_{\mathrm{d} \max }-$ maximum daily water consumption, $\mathrm{m}^{3} \cdot \mathrm{d}^{-1}$,

$\mathrm{Q}_{\mathrm{h} \mathrm{sr}}-$ average hourly water consumption, $\mathrm{m}^{3} \cdot \mathrm{d}^{-1}$,

$\mathrm{Q}_{\mathrm{h} \max }$ - maximum hourly water consumption, $\mathrm{m}^{3} \cdot \mathrm{d}^{-1}$,

$\mathrm{N}_{\mathrm{d}}$ - daily irregularity coefficient,

$\mathrm{N}_{\mathrm{h}}$ - hourly irregularity coefficient.

\section{Results of calculations}

Using data from a period of 8 to 17 years pertaining to water consumption in 7 water supply systems, accounting for formulas (1), (2) and (3), the values of indicators characterizing water consumption in terms of the amount and irregularity were calculated.

The water consumption per capita indicators - minimum, maximum, arithmetic mean and median - have been compiled in Table 2, ordering the systems from the lowest to the highest number of recipients.

The values of water consumption per capita in the analyzed systems were higher for systems with a greater number of recipients, which may be connected with the class of sanitary equipment. An exception to this was the system supplying the villages of Parchów and Pogorzeliska. In the case of smaller systems, the calculated indicators are found to be at a very low level. The calculated values are comparable to those given by other authors [10, $11,12,13]$. In individual systems, a drop in the per capita values was observed, which confirms the tendencies occurring throughout the country. 
Table 2. Indicators of water consumption per capita.

\begin{tabular}{|c|c|c|c|c|}
\hline System & \multicolumn{4}{|c|}{ Water consumption per capita } \\
$\mathbf{d m}^{\mathbf{3}} \cdot \mathbf{M}^{-\mathbf{1}} \cdot \mathbf{d}^{-\mathbf{1}}$
\end{tabular}

A further stage was to calculate hourly and daily irregularity coefficients. The obtained results have been provided in Table 3 .

Table 3. Hourly and daily irregularity coefficients.

\begin{tabular}{|c|c|c|}
\hline System & $\begin{array}{c}\text { Hourly } \\
\text { irregularity } \\
\text { coefficient }\end{array}$ & $\begin{array}{c}\text { Daily irregularity } \\
\text { coefficient }\end{array}$ \\
\hline Turów & 1.80 & 1.70 \\
\hline $\begin{array}{c}\text { Parchów and } \\
\text { Pogorzeliska }\end{array}$ & 1.40 & 1.40 \\
\hline Wilków & 1.62 & 1.70 \\
\hline Borek & 1.55 & 1.30 \\
\hline Serby & 1.73 & 1.40 \\
\hline $\begin{array}{c}\text { Nowogród } \\
\text { Bobrzański }\end{array}$ & - & 1.30 \\
\hline Chocianów & 2.07 & 1.28 \\
\hline
\end{tabular}

Irregularity coefficients reach values corresponding to the range or a bit lower than those indicated in the "Guidelines" for settlements units of up to 20 thousand inhabitants.

Further analysis pertained to the irregularity of water consumption in various time frames. Due to the significant variation in quantity, the percentage of water consumption in the selected systems was compared. A compilation of water use in subsequent months of the year has been presented in Fig. 1. 


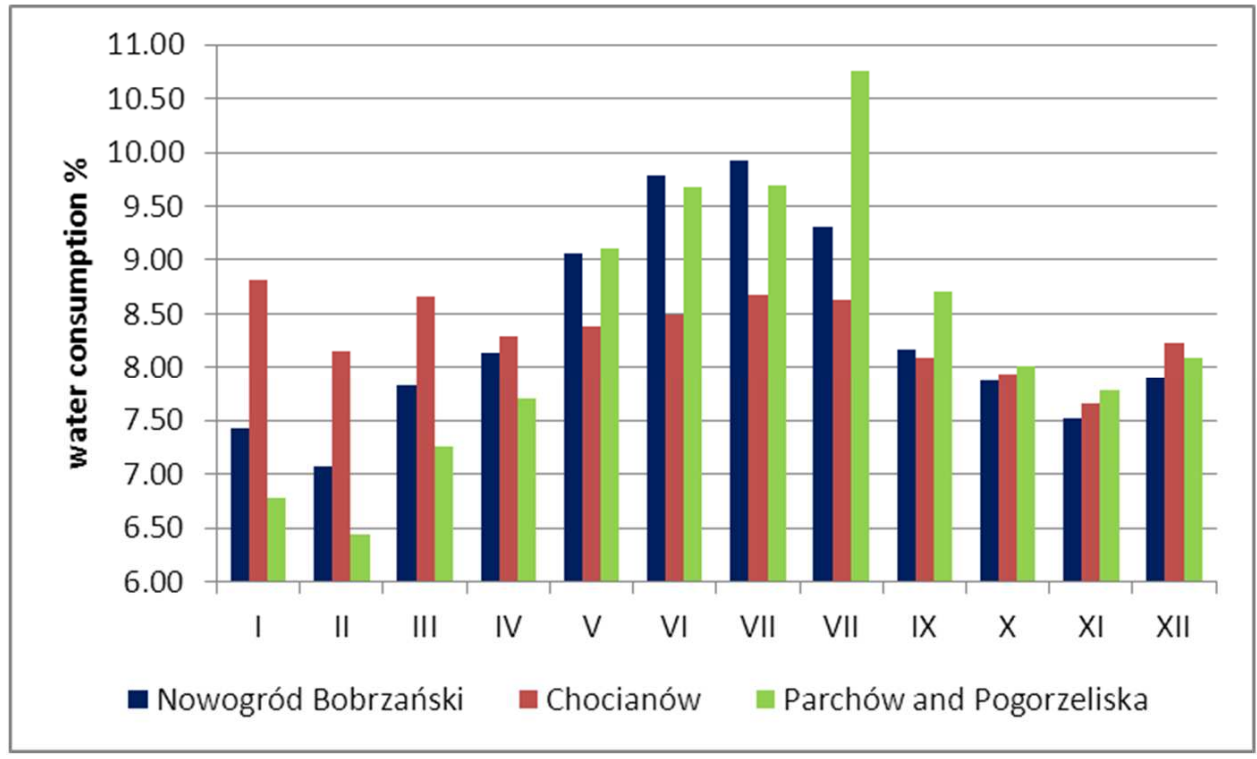

Fig. 1. Variability of water consumption in the individual months of the year.

The highest water consumption in the summer months involved systems supplying villages, which was caused by high water use for needs connected with the running of farms. The lowest water consumption was observed during the winter period, where water was used mainly for household needs. In the case of systems supplying water to cities, a characteristic course of seasonal variation was not observed.

The next stage was the analysis of the irregularity of water consumption over a week. The course of variation in water consumption in the following days of the week has been presented for systems supplying villages in Fig. 2, and for systems supplying cities in Fig. 3.

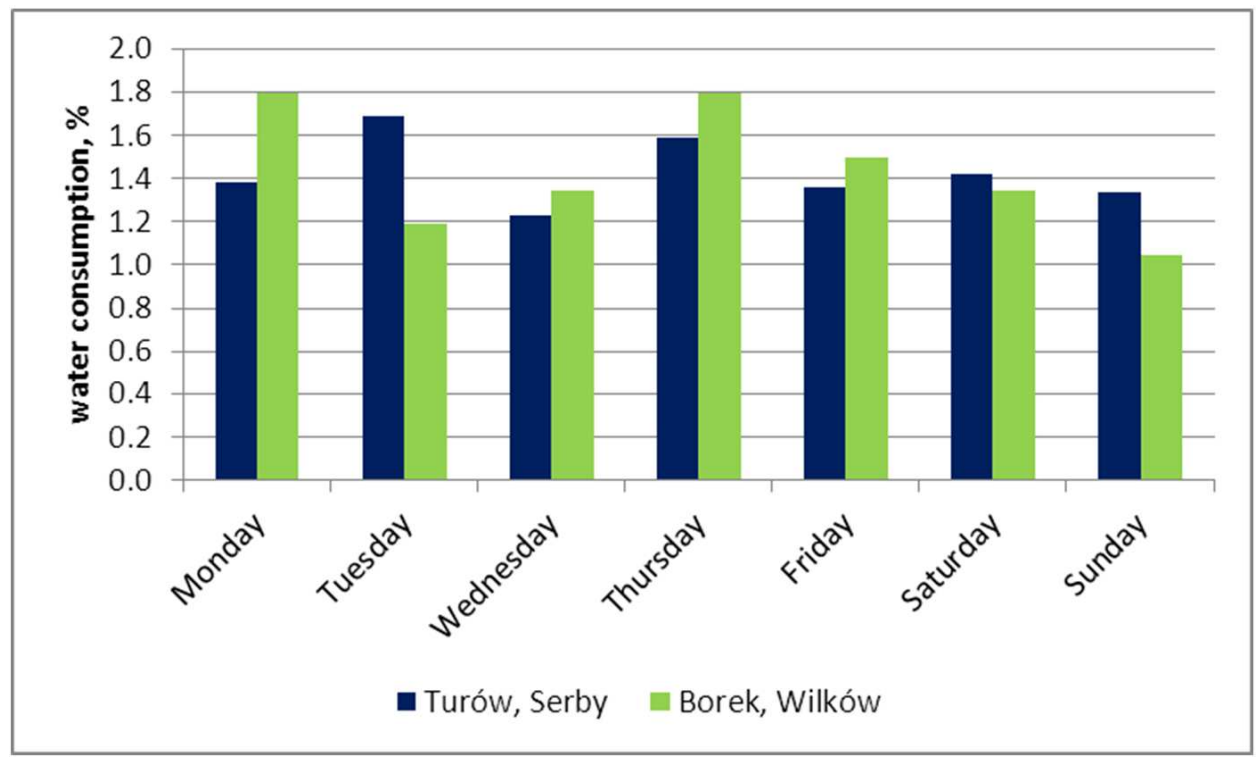

Fig. 2. Variation in water consumption on individual days of the week in systems supplying villages. 


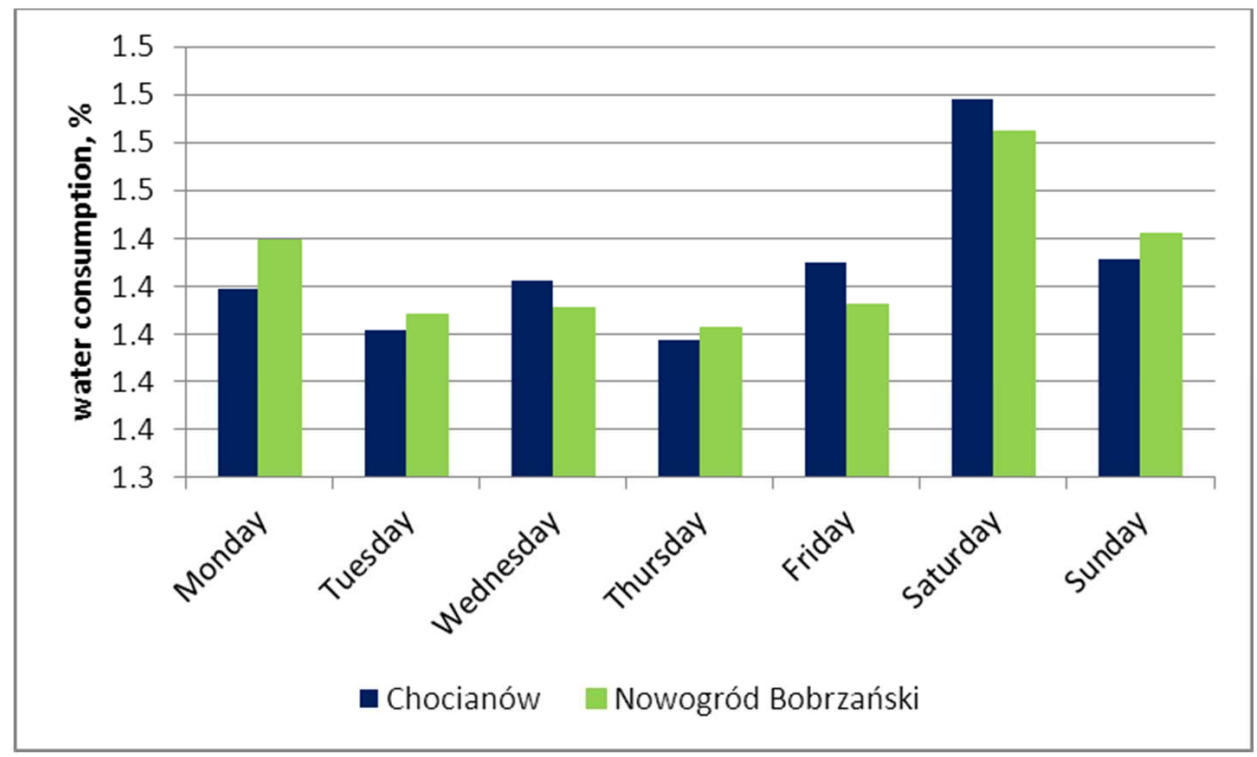

Fig. 3. Irregularity of water consumption on individual days of the week in systems supplying cities.

The carried out compilation confirmed the presence of a weekly cycle of water consumption. The irregularity of water use on the individual days of the week is characterized by a characteristic course reflecting the lifestyle of the inhabitants. Fig. 2 shows increased water consumption on Mondays and Thursdays in the case of the Borek and Wilków systems, as well as on Tuesdays and Thursdays in Turów and Serby, which is connected with preparation by the inhabitants for markets which take place on the subsequent days.

In the case of cities, water consumption over the course of a week is less varied than in villages; increased water consumption at the weekend is noted, with the highest values understood to occur on Saturdays.

A further step was to compare the hourly distribution of water consumption. Graphs of water use over the course of a day have been presented in Fig. 4 for villages, and Fig. 5 for the city. 


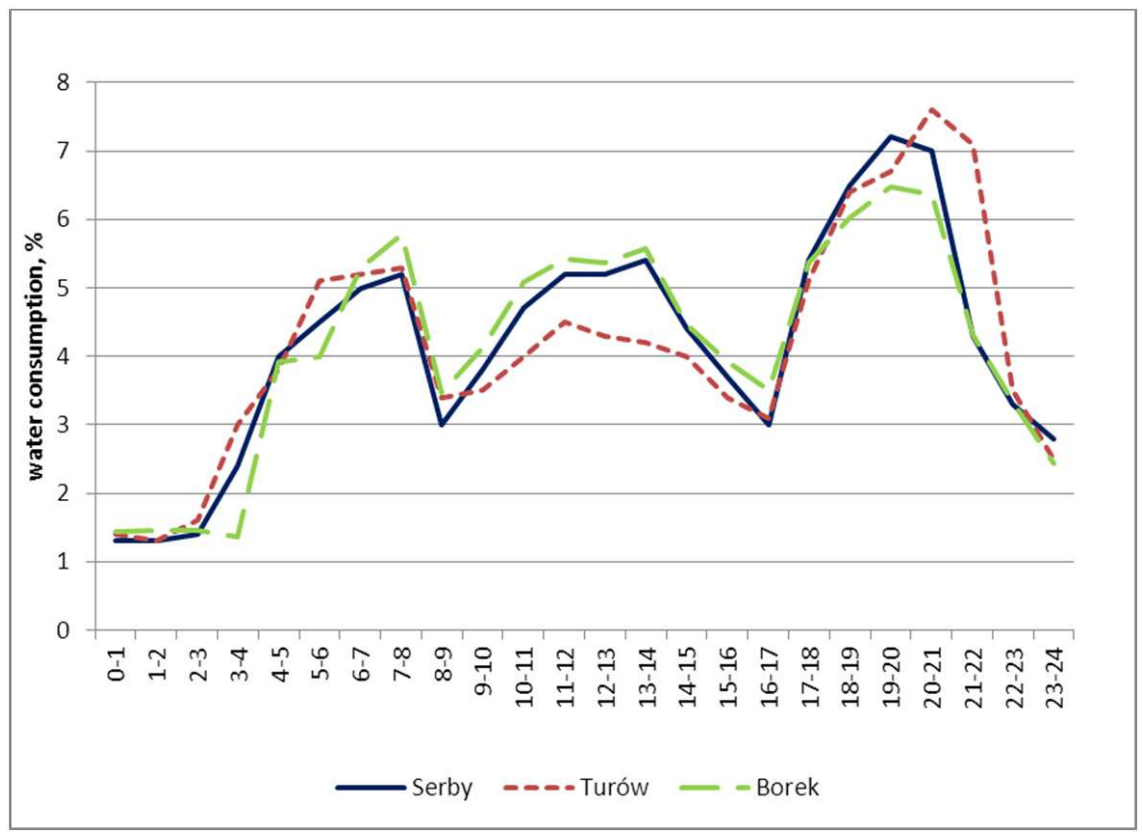

Fig. 4. Hourly distribution of water consumption in systems supplying villages.

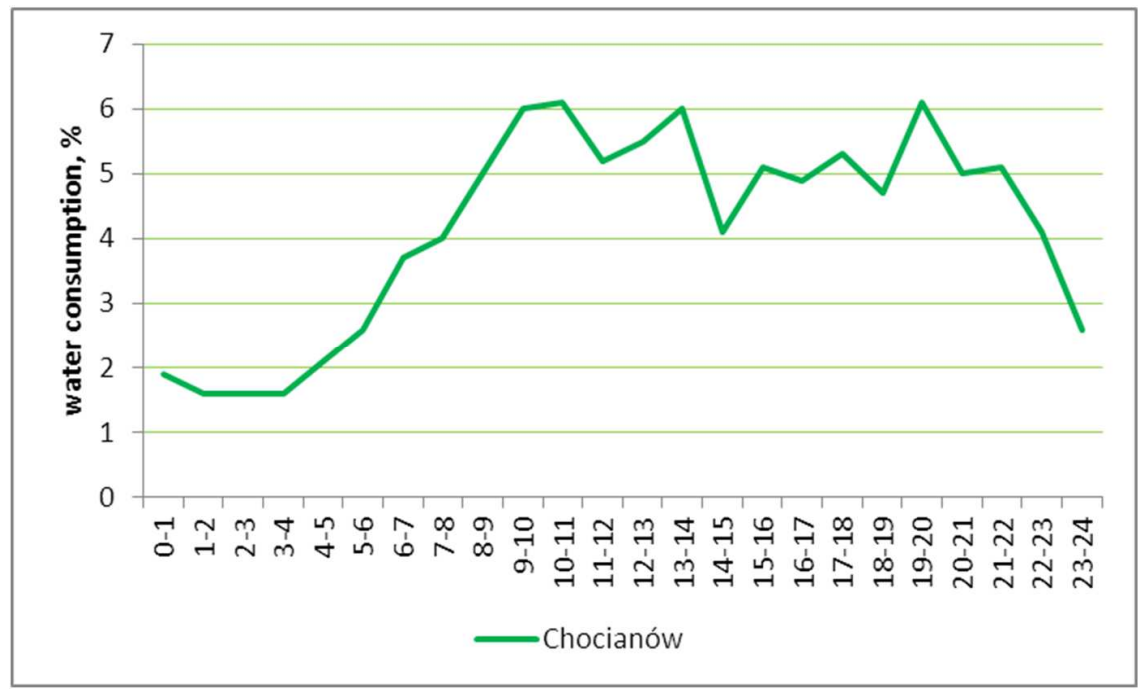

Fig. 5. Hourly distribution of water consumption in system supplying the city.

From the comparison of water consumption over the course of 24 hours, it turns out that, in village areas, the hourly distribution takes a characteristic course, i.e. three peaks of water consumption are typical: morning, afternoon and evening, which is connected with the specifics of farm work. The hours characterized by the highest water consumption coincide, though the percentage distribution is different. A different course occurs in the system supplying the city, where increased water consumption takes place at about noon and remains until the evening hours. 


\section{Conclusions}

An analysis of water consumption in 7 water supply systems, which are diverse in terms of the number of recipients and intended use of water, made it possible to state that the irregularity of water use is influenced by many factors, such as: meteorological factors, the lifestyle of the inhabitants and carrying out responsibilities connected with running a household.

The indicators of water consumption per capita show decreasing tendencies observed throughout Poland. In many cases, the calculated values of the indicator are lower than specified in the Ordinance of the Minister of Infrastructure, and even similar to values considered to be limiting to maintaining an adequate level of life by the inhabitants. A relationship between water consumption per capita and the size of the community was observed, with the smaller the town the lower the consumption per capita. The values of hourly and daily irregularity coefficients do not diverge from those provided by the "Guidelines".

A characteristic course, different for systems supplying water to cities and villages, can be noticed when comparing water consumption in the specified time frames, especially over the course of week and day. This is a reflection of the lifestyle of the inhabitants and the work they engage in connected with running farms and doing housework.

Conclusions regarding the irregularity of water use are significant to the exploitation of water supply systems in terms of the time water supplied to recipients is stored, as well as the rationalization of operating costs.

\section{References}

1. Guidelines for programming water demand and sewage volume in urban settlement units (Warsaw, 1991)

2. J. Rak, B. Tchórzewska-Cieślak, JCEEA, 42, 9 (2007)

3. J. Rak, K. Pietrucha-Urbanik, M. Solecka, JCEEA, 59, 8 (2012)

4. D. Papciak, K. Pietrucha-Urbanik, I. Skrzypczak, B. Tchórzewska-Cieślak, AEP, 43, 10 (2017)

5. E. Ogiołda, I. Nowogoński, M. Walas, RI, 4 (2015)

6. E. Ogiołda, M. Kozaczek, QEED, 9 (2013)

7. E. Ogiołda, I. Nowogoński, R. Kłonowska, QEED, 10 (2014)

8. E. Ogiołda, I. Nowogoński, P. Pietrzak, CEER (to be published)

9. K. Knapik, J. Bajer, Wodociagi (WPK Kraków, 2011)

10. H. Hotloś, EP, 32, 4 (2010)

11. D. Usidus, ASEP, 16 (2010)

12. M. Mikołajczyk, Inst., 3 (2012)

13. T. Bergel, GWiTS, 3 (2013) 